\title{
Distiller's dried grains with solubles (Zea mays L.) in feeding sheep on nitrogen balance
}

\section{Grão seco de destilaria com solúveis (Zea mays L) na alimentação de ovinos sobre o balanço de nitrogênio}

\author{
Luiz Juliano Valério Geron ${ }^{1 *}$; Jocilaine, Garcia ${ }^{1}$; Sílvia Cristina de Aguiar ${ }^{1}$; \\ Kallynka Samara Martins Coelho²; Ilda de Souza Santo²; Alexandre de Lima \\ Souza $^{3}$; Anderson de Moura Zanine ${ }^{4}$; Eurico Lucas de Sousa Neto ${ }^{1}$; \\ Leomar Custódio Diniz ${ }^{2}$; José Wilson Pires Carvalho ${ }^{1}$
}

\begin{abstract}
The objective of this study was to evaluate the effects of diets supplemented with $0.0,8.0,16.0$, and $24.0 \%$ distiller's dried grain solubles (DDGS) on nitrogen $(\mathrm{N})$ intake, fecal and urinary $\mathrm{N}$ excretion, and $\mathrm{N}$ absorption and retention ( $\mathrm{N}$ balance, NB) by feeding sheep. Four sheep of unidentified race were used, with an average body weight of $23.5 \pm 1.5 \mathrm{~kg}$, and housed in metabolism cages. We used a $4 \times 4$ Latin square design for the experimental design, and each experimental period lasted for 20 days. Data on $\mathrm{N}$ intake (NI), fecal N, urinary $\mathrm{N}$, absorbed $\mathrm{N}$, and NB were expressed in $\mathrm{g} \mathrm{day}^{-1}$; percentage of NI and grams per kilogram of metabolic weight $\mathrm{g}\left(\mathrm{kg}^{0.75}\right)^{-1}$ were subjected to analysis of variance (ANOVA) and regression analysis at 5\% probability. Inclusion of the different concentrations of DDGS in sheep diets had no effect on NI (mean of $15.11 \mathrm{~g} \mathrm{animal}^{-1}$ day $^{-1}$ ), nor on fecal and urinary $\mathrm{N}$ excretion (mean of 5.16 and $0.16 \mathrm{~g}_{\text {animal }}{ }^{-1}$ day $^{-1}$, respectively). Moreover, DDGS supplementation did not alter NB or $\mathrm{N}$ absorption (mean of 9.79 and $9.95 \mathrm{~g}_{\text {animal }}{ }^{-1}$ day $^{-1}$, respectively). Thus, it can be concluded that inclusion of up to $24 \%$ of DDGS in feed does not affect NI, fecal and urinary N excretion, and NB in sheep.
\end{abstract}

Key words: Absorption. Nitrogen intake. Feces. Urine.

\section{Resumo}

O presente estudo teve como objetivo avaliar a inclusão de 0,$0 ; 8,0 ; 16,0$ e $24,0 \%$ de GSDS na alimentação de ovinos sobre o consumo e a excreção fecal e urinaria de nitrogênio; absorção e retenção de nitrogênio. Foram usados quatro ovinos de raça não definida, com peso corporal de $23,5 \pm 1,5 \mathrm{~kg}$ alojados em gaiolas de metabolismo. Foi utilizado um delineamento experimental em quadrado latino 4X4. Cada período experimental teve duração de 20 dias. Os dados de consumo de nitrogênio (N), $\mathrm{N}$ fecal, $\mathrm{N}$ urinário, $\mathrm{N}$ absorvido e balanço de nitrogênio $(\mathrm{BN})$ expressos em $\mathrm{g} \mathrm{dia} \mathrm{a}^{-1} ; \%$ do nitrogênio consumido (NC) e gramas por quilograma de peso metabólico $\left(\mathrm{g} \mathrm{kg}^{0,75-1}\right)$ foram submetidos á análise de variância (ANOVA) e testados utilizando equação de regressão a $5 \%$ de probabilidade. A inclusão de 0,$0 ; 8,0 ; 16,0$ e 24,0\% de GSDS na alimentação de ovinos não alterou o consumo de nitrogênio

\footnotetext{
1 Profs., Universidade do Estado de Mato Grosso, UNEMAT, Pontes e Lacerda, MT, Brasil. E-mail: 1jgeron@yahoo.com.br; jo@ unemat.br; scaguiar@unemat.br; euriconeto@unemat.br

2 Discentes de Graduação, Curso de Zootecnia, UNEMAT, Pontes e Lacerda, MT, Brasil. E-mail: coelho-ksm@hotmail.com

3 Prof., Universidade Federal de Mato Grosso, UFMT, Cuiabá, MT, Brasil. E-mail: alexandre@ufmt.br

4 Prof., Universidade Federal do Maranhão, UFMA, Chapadinha, MA, Brasil. E-mail: anderson.zanini@ibest.com.br

* Author for correspondence
} 
(CN), com valor médio de $15,11 \mathrm{~g}_{\text {animal }}{ }^{-1} \mathrm{dia}^{-1}$. Da mesma forma, a inclusão dos diferentes níveis de GSDS não alteraram a excreção fecal e urinaria de nitrogênio com valores médios de 5,16 e $0,16 \mathrm{~g}$ animal $^{-1}$ dia $^{-1}$, respectivamente. A inclusão de 0,$0 ; 8,0 ; 16,0$ e 24,0\% de GSDS na alimentação de ovinos, não influenciou no valor de balanço e na absorção de nitrogênio com valores médios de 9,79 e 9,95 g animal $^{-1}$ dia $^{-1}$, respectivamente. Portanto, a inclusão de até $24 \%$ de grão seco de destilaria com solúveis na alimentação de ovinos não altera o consumo, a excreção fecal e urinaria e o balanço de nitrogênio.

Palavras-chave: Absorção. Consumo de nitrogênio. Fezes. Urina.

\section{Introduction}

The rising global demand for fuel products is providing new opportunities for ethanol distilleries in Brazil to explore the use of alternative yeast fermentation substrates, such as cereal grains, for the production of ethanol (SCHONE, 2015). Ethanol is derived from the fermentation process, during which a byproduct called "distiller's dried grain solubles", or DDGS, is produced (RAUSCH; BELYEA, 2005; KIM; DALE, 2005). In Portuguese: "grão seco de destilaria com solúveis" - GSDS (GERON et al., 2017).

Previous research by Nuez-Ortín and Yu (2009), Salim et al. (2010), and Geron et al. (2017), among others, has shown that DDGS is usually composed of $87.0-93.0 \%$ dry matter (DM), $28.1-32.9 \%$ crude protein (CP), $8.2-16.5 \%$ ethereal extract (EE), and 19.7 -4 9.5\% neutral detergent fiber (NDF), and typically contains a total digestible nutrient (TDN) content in the $69.6-78.5 \%$ range.

According to the Associação dos Produtores de Soja e Milho de Mato Grosso - APROSOJA (2012), as well as Schone (2015) and Geron et al. (2017), DDGS produced in Brazil consists of, on average, 90.6-96.1\% DM, 25.7-35.9\% CP, 2.3-8.9\% EE, and $10.3 \%$ crude fiber $(\mathrm{CF})$, the latter a component of DM.

Geron et al. (2017) considered DDGS to be a protein-rich food, as greater than $70 \%$ of the $\mathrm{CP}$ is in the form of the $\mathrm{B} 2$ fraction (true protein); in addition, DDGS contains high levels of carbohydrates bound to the cell wall. Moreover, DDGS produced in Brazil has a lower in vitro digestibility coefficient for DM and CP than does standard soybean meal protein.
Regular ingestion of DDGS by ruminants may, however, affect the release of ammoniacal nitrogen $(\mathrm{N})$ in the rumen and consequently alter the ruminal environment and the use of dietary protein. The difference between the amount of $\mathrm{N}$ consumed in the diet and the amount of $\mathrm{N}$ excreted in the urine and feces by an animal is defined as its $\mathrm{N}$ balance - NB (BERCHIELLI et al., 2011). In general, NB can be positive, negative, or equal to zero ( $\mathrm{N}$ intake and excretion are more or less the same), which can be used as a metric in assessments of animal health. According to Caldas Neto et al. (2008), protein sources of high degradability are generally used more efficiently when associated with easily digestible energy sources, allowing for the synchronization of energy and protein sources and thus improving efficiency in the synthesis of microbial protein that is fixation of the ammoniacal nitrogen present in the rumen.

Thus, the goal of this study was to evaluate the effects of diets supplemented with 0.0, 8.0, 16.0, and $24.0 \%$ DDGS on $\mathrm{N}$ intake, fecal and urinary $\mathrm{N}$ excretion, and $\mathrm{N}$ absorption and NB in sheep.

\section{Material and Methods}

The study was conducted in the "Setor de Metabolismo Animal (SeMA) e Laboratório de Análise de Alimentos e Nutrição Animal (LAANA)" of the "Universidade do Estado de Mato Grosso (UNEMAT)".

Four undefined breeds of sheep were used, with a mean body weight $(\mathrm{BW})$ of $23.5 \pm 1.5 \mathrm{~kg}$. The sheep were housed in metabolism cages, which had individual feeders and drinkers, in accordance tiwh 
protocol 008/2016 of the Comissão de Ética no Uso Animal (CEUA/UNEMAT).

The sheep were deverminated with an ivermectinbased product (Ivomec ${ }^{\circledR}$ Merial injectable, at a concentration of $1 \mathrm{~g}$ of ivermectin per $100 \mathrm{ml}$ of vehicle), and $1 \mathrm{ml}$ of vermifuge for each $50 \mathrm{~kg}$ of BW was applied to the sheep $15 \mathrm{~d}$ prior to the beginning of the experimental period.

The DDGS added to the diets originated from the fermentation of corn grain (Zea mays L.) as a byproduct of the ethanol production process, and was obtained from an ethanol distillery located in the municipality of Campos de Júlio - MT (USIMAT), approximately $250 \mathrm{~km}$ from the University campus of Pontes e Lacerda - UNEMAT and $450 \mathrm{~km}$ from Cuiabá - MT.

The sheep were distributed in a $4 \times 4$ Latin square design consisting of four sheep, four time periods, and four experimental treatments consisting of 0.0 ,
8.0, 16.0, and 24.0\% DDGS supplementation.

The experiment was conducted over an $80 \mathrm{~d}$ period subdivided into four experimental periods of $20 \mathrm{~d}$ of feeding, $14 \mathrm{~d}$ for conditional adaptation, $5 \mathrm{~d}$ for the collection of leftover, feces, and urine samples, and $1 \mathrm{~d}$ for ruminal fluid collection. During the experimental period, total amount of feces and leftovers per animal day ${ }^{-1}$ were measured, and samples of food, leftovers, and feces were collected. Fecal collecting bags were attached to each animal $5 \mathrm{~d}$ before fecal collection in each experimental period. Management of the animals during the adaptation and collection periods followed the protocol described by Geron et al. (2015a).

Roughage feed consisted of corn silage, and the concentrate used in the experimental diets consisted of ground corn grain, soybean meal, and DDGS (Table 1 ), with the exception of the $0.0 \%$ treatment, which contained no DDGS.

Table 1. Bromatological composition of the foods used in the formulation of the different experimental rations containing the distiller's dried grain with soluble (DDGS).

\begin{tabular}{lccccccccc}
\hline Foods & \multicolumn{8}{c}{ \% of nutrients expressed in DM } \\
\hline & \% DM & OM & CP & EE & NDF & ADF & TCH & NFC & TDN \\
\hline CS & 29.33 & 93.36 & 7.54 & 3.59 & 54.38 & 28.58 & 82.23 & 27.85 & 61.30 \\
CG & 90.99 & 97.38 & 9.20 & 5.85 & 14.05 & 6.47 & 82.33 & 68.28 & 86.03 \\
SB & 91.29 & 92.69 & 49.26 & 2.19 & 15.37 & 10.97 & 41.24 & 25.87 & 80.73 \\
DDGS & 90.04 & 98.00 & 34.41 & 4.47 & 48.80 & 15.37 & 59.11 & 10.31 & 78.50 \\
\hline
\end{tabular}

CS: corn silage; CG: corn grain; SB: soybean meal; DM: dry matter; OM: organic matter; CP: crude protein; EE: ethereal extract; NDF: neutral detergent fiber; ADF: acid detergent fiber; TCH: total carbohydrate; NFC: non-friable carbohydrates and NDT: total digestible nutrients.

Diets were balanced to contain 0.0, 8.0, 16.0, and $24.0 \%$ DDGS. The proportion of roughage to concentrate used in the experimental rations was $65 \%$ corn silage and $35 \%$ concentrate, and diets contained, on average, $13.5 \%$ crude protein (isoprotein) and $68.5 \%$ total digestible nutrients (isoenergetic), in accordance with NRC (2007) recommendations (Table 2).

Ten $g$ of mineral mixture per animal was added directly to the concentrate at the time of feeding, that is, twice daily ( $5 \mathrm{~g}$ of meal salt $\mathrm{t}^{-1}$ animal $\left.{ }^{-1}\right)$. The chemical composition of the mineral salt is shown in Table 3.

Feed was provided ad libitum twice daily, at 06h:00 and 18h:00, in volumes high enough to ensure approximately $10.0 \%$ of leftovers daily. Monitoring of leftovers was performed daily prior to the day's first feeding. 
Corn silage samples were initially collected from different areas within the silo to determine DM content. During the experiment, however, samples were collected from the leftovers of the rations (unit: animal ${ }^{-1}$ period $^{-1}$ treatment $^{-1}$ ).

To carry out fecal collection, a nappa bag was attached to each ovine 5 days before the experimental period. Feces produced by each animal were weighed daily in the morning and homogenized, and composite samples were collected that corresponded to $10 \%$ of total fecal weight. The samples were stored in plastic bags, identified by animal and experimental period, and stored in a freezer at $-10{ }^{\circ} \mathrm{C}$ for further analysis.

Table 2. Percentage and bromatological composition of rations containing inclusion levels of distiller's dried grains with solubles (DDGS).

\begin{tabular}{lcccc}
\hline Ingredients & \multicolumn{3}{c}{ Levels of inclusion of the DDGS } \\
\hline & $0.0 \%$ & $8.0 \%$ & $16.0 \%$ & $24.0 \%$ \\
\hline Corn silage (CS) & 65.0 & 65.0 & 65.0 & 65.0 \\
Corn grain (CG) & 21.5 & 18.0 & 14.5 & 11.0 \\
Soybean meal (SB) & 13.5 & 9.0 & 4.5 & 0.0 \\
Distillers dried grains with solubles (DDGS) & 0.0 & 8.0 & 16.0 & 24.0 \\
\cline { 2 - 5 } Total & 100.0 & 100.0 & 100.0 & 100.0 \\
\hline & Bromatological composition of rations (\% of DM) & & \\
\hline dry matter (DM) & 50.95 & 50.86 & 50.77 & 50.69 \\
organic matter (OM) & 94.13 & 94.39 & 94.66 & 94.92 \\
crude protein (CP) & 13.53 & 13.74 & 13.96 & 14.17 \\
ethereal extract (EE) & 3.89 & 3.94 & 4.00 & 4.05 \\
neutral detergent fiber (NDF) & 40.44 & 43.16 & 45.88 & 48.61 \\
acid detergent fiber (ADF) & 21.45 & 21.96 & 22.47 & 22.98 \\
total carbohydrate (TCH) & 76.72 & 76.71 & 76.70 & 76.69 \\
non-fibrous carbohydrates (NFC) & 36.27 & 33.55 & 30.82 & 28.09 \\
total digestible nutrients (TDN) & 69.24 & 68.88 & 68.51 & 68.15 \\
\hline
\end{tabular}

Table 3. Chemical composition of mineral salt supplied to sheep.

\begin{tabular}{lc}
\hline Nutrients present in mineral salt & Amount of nutrients \\
\hline Calcium (Ca) $\mathrm{g} \mathrm{kg}^{-1}$ & 120.00 \\
Phosphor (P) $\mathrm{g} \mathrm{kg}^{-1}$ & 85.00 \\
Sulfur (S) $\mathrm{g} \mathrm{kg}^{-1}$ & 16.00 \\
Sodium (Na) $\mathrm{g} \mathrm{kg}^{-1}$ & 148.00 \\
Cobalt (Co) mg kg-1 & 50.00 \\
Copper (Cu) mg kg-1 & 500.00 \\
Selenium (Se) mg kg & 16.00 \\
Zinc (Zn) $\mathrm{mg} \mathrm{kg}^{-1}$ & $4,800.00$ \\
\hline
\end{tabular}


Urine was collected in plastic buckets placed underneath the metabolism cages and covered with screens to avoid contamination by hair, feed, and feces, and $20 \mathrm{~mL}$ of hydrochloric acid (HyC) $(1: 1)$ was added to each bucket to prevent $\mathrm{N}$ volatilization and possible fermentation. Urine collection was performed daily at the same time each morning; samples equaling $10 \%$ of the total urine collected were combined in a single glass bottle identified by animal over the extent of each experimental period.

Food, leftover, and fecal samples were dried in an oven at $55^{\circ} \mathrm{C}$ for $72 \mathrm{~h}$ following the end of the experimental period, then processed in a knife mill with $1 \mathrm{~mm}$ sieves and homogenized into equal amounts based on dry weight, to form composite samples of feces and leftovers (units: animal ${ }^{-1}$ period $^{-1}$ experimental ration $^{-1}$ ).

Determination of the $\mathrm{N}$ content of the food, leftover, and urine and fecal samples was performed using the semi-micro-Kjeldahl method, with 6.25 established as the conversion factor for CP. Mineral matter (MM) analysis was performed via the muffle incineration method, at a temperature of $600{ }^{\circ} \mathrm{C}$; $\mathrm{OM}$ was estimated by calculating the difference (DM-MM), whereas EE content was determined via extraction by washing with petroleum ether, in accordance with the protocol described by Silva and Queiroz (2002). For determination of NDF and acid detergent fiber (ADF) concentrations, we used the method described by Van Soest et al. (1991).
Concentrations of $\mathrm{N}$ in the sheep urine were determined using the Kjeldahl method, as described by Silva and Queiroz (2002), and NB was estimated using the formula $\mathrm{NB}=[\mathrm{N}$ provided $\mathrm{g}-\mathrm{N}$ of the leftovers $\mathrm{g}$ ) - ( $\mathrm{N}$ in feces $\mathrm{g}+\mathrm{N}$ in urine $\mathrm{g})$ ], as described by Geron et al. (2015a). The amount of $\mathrm{N}$ absorbed (NA) by sheep was calculated using the equation $\mathrm{NA}=[(\mathrm{N}$ provided $\mathrm{g}-\mathrm{N}$ of the leftovers $\mathrm{g})$ - ( $\mathrm{N}$ in the feces $\mathrm{g})$ ] and $\mathrm{N}$ intake (NI) was estimated using the equation $\mathrm{NI}=[(\mathrm{N}$ provided $\mathrm{g}-\mathrm{N}$ in leftovers g)], as described by Moreno et al. (2010).

Analysis of variance was performed in accordance with the "Sistema de Análise Estatística e Genética - SAEG (UFV, 2007)" for all variables (NI, urinary and fecal $\mathrm{N}$ production, NA, and NB); differences in these variables among treatments were tested via regression analysis at 5\% significance.

\section{Results and Discussion}

Inclusion of $0.0,8.0,16.0$, and $24.0 \%$ DDGS in sheep feed did not alter NI [mean $=15.11 \mathrm{~g}$

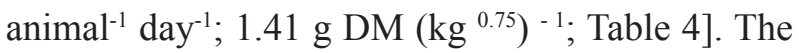
highest proportion $(\sim 70 \%)$ of CP in DDGS is in the form of the B2 fraction, which is of intermediate degradability (GERON et al., 2017), and may have corroborated for the constant intake of CP protein in sheep. In addition, the experimental rations presented isoproteic values of $13.5 \%$ of $\mathrm{CP}$ and isoenergetic of $68.5 \%$ of TDN (Table 2 ), factors that may have contributed to the NI results. 
Table 4. Values of intake, faecal and urinary nitrogen excretion, nitrogen balance, nitrogen absorbed ( $\mathrm{g}$ animal ${ }^{-1}$ day$\left.{ }^{1}\right)$ and relation of the nitrogen balance with nitrogen absorbed for lambs fed different levels of distiller's dried grain (DDGS).

\begin{tabular}{|c|c|c|c|c|c|c|}
\hline \multirow[t]{2}{*}{ Variables } & \multicolumn{4}{|c|}{$\begin{array}{l}\text { Inclusion levels of distiller's dried grain with soluble } \\
\text { (DDGS) \% }\end{array}$} & \multirow[t]{2}{*}{ Regression } & \multirow[t]{2}{*}{$\% \mathrm{CV}$} \\
\hline & 0.0 & 8.0 & 16.0 & 24.0 & & \\
\hline NI g animal ${ }^{1}$ day $^{-1}$ & 14.01 & 15.50 & 16.06 & 14.86 & $Y=15.11$ & 14.26 \\
\hline NI g $\left(\mathrm{kg}^{0,75}\right)^{-1}$ & 1.35 & 1.45 & 1.48 & 1.37 & $\mathrm{Y}=1.41$ & 13.98 \\
\hline FN g animal ${ }^{1}$ day $^{-1}$ & 4.90 & 5.20 & 5.60 & 5.08 & $Y=5.16$ & 23.20 \\
\hline FN g $\left(\mathrm{kg}^{0,75}\right)^{-1}$ & 0.48 & 0.49 & 0.52 & 0.47 & $Y=0.48$ & 9.48 \\
\hline FN \% NI & 35.67 & 34.39 & 35.01 & 34.33 & $Y=34.52$ & 4.24 \\
\hline UN g animal ${ }^{1}$ day $^{-1}$ & 0.18 & 0.15 & 0.16 & 0.15 & $Y=0.16$ & 38.30 \\
\hline $\mathrm{UN} g\left(\mathrm{~kg}^{0,75}\right)^{-1}$ & 0.017 & 0.014 & 0.016 & 0.014 & $\mathrm{Y}=0.015$ & 38.97 \\
\hline UN \%NI & 1.48 & 1.01 & 1.09 & 1.04 & $\mathrm{Y}=1.15$ & 31.63 \\
\hline NB g animal ${ }^{1}$ day $^{-1}$ & 8.93 & 10.15 & 10.30 & 9.63 & $\mathrm{Y}=9.79$ & 12.37 \\
\hline $\mathrm{NB} g\left(\mathrm{~kg}^{0,75}\right)^{-1}$ & 0.86 & 0.95 & 0.94 & 0.89 & $Y=0.92$ & 8.66 \\
\hline NB \%NI & 62.85 & 64.61 & 63.90 & 64.63 & $Y=64.33$ & 4.47 \\
\hline NA g animal ${ }^{1}$ day $^{-1}$ & 9.12 & 10.30 & 10.46 & 9.77 & $Y=9.95$ & 11.84 \\
\hline NAg $\left(\mathrm{kg}^{0,75}\right)^{-1}$ & 2.85 & 2.98 & 2.88 & 2.97 & $Y=2.92$ & 10.89 \\
\hline NA \%NI & 64.33 & 65.61 & 64.99 & 65.67 & $Y=65.48$ & 4.99 \\
\hline $\mathrm{NB} \mathrm{NI}^{-1}$ & 0.63 & 0.65 & 0.64 & 0.65 & $Y=0.64$ & 4.75 \\
\hline $\mathrm{NB} \mathrm{NA}^{-1}$ & 0.98 & 0.98 & 0.98 & 0.98 & $Y=0.98$ & 1.12 \\
\hline
\end{tabular}

NI: nitrogen intake; $\mathrm{g}\left(\mathrm{kg}^{0,75}\right)^{-1}$ : grams per pound of metabolic weight; $\mathrm{FN}$ : faecal nitrogen; \%NI: percentage of the nitrogen intake; UN: urinary nitrogen; NB: nitrogen balance; NA: nitrogen absorbed.

Our results regarding NI indicated that the slower disappearance rate of $\mathrm{N}$ present in DDGS, due to a higher proportion of the $\mathrm{B} 3$ fraction of $\mathrm{CP}$ of slow ruminal degradation in relation to soybean meal (GERON et al., 2017), had no effect on the ruminal environment and consequently there was a low impact on the negative associative effect, which could reduce NI and DM intake. Thus, inclusion of DDGS in the feed of ruminants containing fast-fermenting carbohydrates corroborates the maintenance of the synthesis of microbial protein, due to the synchronization of energy and protein sources, and consequently maintains $\mathrm{NA}$ and excretion during the ruminal fermentation process in a similar manner to diets containing only soybean meal as a source of crude protein.

Geron et al. (2015a), in a study on NB in sheep fed diets supplemented with different levels of concentrate, showed that supplementation with different amounts of concentrate had a quadratic effect on NI and that maximum NI occurred at concentrate levels of $38 \%$. Here, we used a roughage:concentrate ratio of approximately $65: 35$, a level close to the optimal NI reported by Geron et al. (2015a) when considering the proportion of fibrous carbohydrates and rapid ruminal fermentation.

The inclusion of different concentrations of DDGS in sheep feed had no effect $(p>0.05)$ on fecal nitrogen levels $\left[\mathrm{FN}\right.$; average $=5.16 \mathrm{~g}_{\text {animal }}{ }^{-1}$ day $^{-1} ; 0.48$ g DM $\left(\mathrm{kg}^{0.75}\right)^{-1} ; 34.52 \%$ NI; Table 4].

The reduction in fermentable carbohydrate in the large intestine may reduce the amount of $\mathrm{N}$ in the feces due to decreasing bacterial activity in the colon and cecon, as lower amounts of fermentative 
carbohydrates reduces microbial synthesis and consequently lower excretion of microbial protein and total $\mathrm{N}$ in feces (KOZLOSKI, 2002; GERON et al., 2015a). However, non-fibrous carbohydrate (NFC) concentrations varied greatly among the experimental diets; NFC was $36.27 \%$ for diets containing $0.0 \%$ DDGS, whereas it was $28.09 \%$ in diets containing $24.0 \%$ DDGS. It is likely that this difference was insufficient to induce significant changes in the fermentable substrate that reached the large intestine and altered the concentration of NF of the sheep fed diets supplemented with DDGS.

Addition of DDGS did not influence $(\mathrm{p}>0.05)$ urinary $\mathrm{N}\left[\mathrm{UN}\right.$; mean $=0.16 \mathrm{~g}_{\text {animal }}{ }^{-1}$ day $^{-1} ; 0.015$ g DM $\left(\mathrm{kg}^{0.75}\right)^{-1} ; 1.15 \%$ NI; Table 4]. About 50 $70 \%$ of the $\mathrm{N}$ present in rumen feed is degraded by bacteria during the ruminal fermentation process, during which ammonia is produced and released in the ruminal environment (ALVES et al., 2012; GERON et al., 2015b). Thus, excess $\mathrm{N}$ in the rumen is absorbed by the ruminal wall and enters the bloodstream, where it remains until eventually reaching the liver, where it is transformed into urea. This circulating urea can be partially recycled via saliva or returned to the rumen by transport facilitated by the ruminal wall, but when urea is in excess in the bloodstream, a part of it is excreted in the urine, resulting in endogenous $\mathrm{N}$ losses (KOZLOSKE, 2002; CARVALHO at al., 2010; GERON et al., 2015b). This process was not evident in the present study, most likely because most of the protein in DDGS is in the form of the B2 fraction (true protein of ruminal intermediary degradation) (GERON et al., 2017), which may have caused a small change in the rate of ruminal $\mathrm{N}$ release compared to diets containing a higher proportion of soybean meal, which corroborates with the results obtained for the UN of sheep fed DDGS.

According to Geron et al. (2015b), CP content in the feed influences $\mathrm{N}$ loss via urine, or, more simply, $\mathrm{UN}$ increases as protein content in the diet increases. However, the experimental diets we used here were isoprotic (13.5\% of $\mathrm{CP})$ and within the standards established by the NRC (2007), which corroborated with reduced $\mathrm{N}$ loss through the urinary tract. However, FN is not affected by dietary CP content but rather by the quality and fermentation profile of the diet, which may have contributed to the higher levels of FN than UN observed in the present study.

The inclusion of different concentrations of DDGS in sheep feed had no effect $(\mathrm{p}>0.05)$ on NB

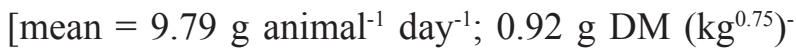
${ }^{1}$; 64.33\% NI; Table 4]. Thus, addition of DDGS to sheep feed results in an NB similar to that of traditional soybean meal (the conventional protein source), considering the ammoniacal $\mathrm{N}$ pool with the dietary energy pool (OM fermentation), which promotes efficient use of available nutrients in the rumen (GERON et al., 2015b, 2015c). In general, the lower energy expenditure for ammonia recycling in the ruminal environment allows the targeting of this pool of energy and nutrients by microbes, thus increasing the microbial growth rate and consequently improving the productive efficiency of the animals.

Supplementing sheep feed with DDGS also had no effect $(\mathrm{p}>0.05)$ on NA [mean $=9.95 \mathrm{~g} \mathrm{animal}^{-1}$

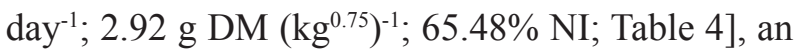
indication that DDGS promotes rates of degradation and release in the ruminal environment similar to those induced by conventional CP (i.e., soybean meal). This may favor maintenance of the ruminal environment, as well as rumen efficiency and bacterial activity, in relation to the synchronization of the sources of $\mathrm{N}$ as the energy within the rumen (ALVES et al., 2014).

Thus, we conclude that inclusion of up to $24.0 \%$ of DDGS in sheep feed does not alter NI, NB, or losses of fecal and urinary $\mathrm{N}$.

\section{Acknowledgements}

Financial support for this research was provided by the "Conselho Nacional de Desenvolvimento Cientifico e Tecnológico - CNPq". 


\section{References}

ALVES, E. M.; MAGALHÃES, D. R.; FREITAS, M. A.; SANTOS, E. J.; PEREIRA, M. L.; PEDREIRA, M. S. Nitrogen metabolism and microbial synthesis in sheep fed diets containing slow release urea to replace the conventional urea. Acta Scientiarum. Animal Sciences, Maringá, v. 36, n. 1, p. 55-62, 2014.

ALVES, E. M.; PEDREIRA, M. S.; PEREIRA, M. L. A.; ALMEIDA, P. J. P.; GONSALVEZ NETO, J.; FREIRE, L. D. R. Farelo da vagem de andiroba associado a níveis de ureia na alimentação de ovinos: balanço de nitrogênio, N-ureico no plasma e parâmetros ruminais. Acta Scientiarum: Animal Science, Maringá, v. 34, n. 3, p. 287-295, 2012.

ASSOCIAÇÃO DOS PRODUTORES DE SOJA E MILHO DE MATO GROSSO - APROSOJA. Verticalização do milho marca circuito APROSOJA em Campos de Júlio. Campos de Júlio: Aprosoja, 2012. Disponível em: http:/tvcentrooeste.com/verticalizacaode-milho-marcacircuito-aprosoja-em-campos-de-julio>. Acesso em: 6 jul. 2012.

BERCHIELLI, T. T.; PIRES, A. V.; SIMONE, G. O. Nutrição de ruminantes. 2. ed. Jaboticabal: Funep, 2011. $583 \mathrm{p}$.

CALDAS NETO, S. F.; ZEOULA, L. M.; PRADO, I. N.; BRANCO, A. F.; KAZAMA, R.; GERON, L. J. V.; MAEDA, E. M.; FERELI, F. Proteína degradável no rúmen na dieta de bovinos: digestibilidade total e parcial dos nutrientes e parâmetros ruminais. Revista Brasileira de Zootecnia, Viçosa, MG, v. 37, n. 6, p. 1094-1102, 2008.

CARVALHO, G. G. P.; GARCIA, R.; PIRES, A. J. V.; SILVA, R. R.; PEREIRA, M. L. A.; VIANA, P. T.; SANTOS,A. B.; PEREIRA, T.C. J. Balanço de nitrogênio, concentrações de ureia e síntese de proteína microbiana em caprinos alimentados com dietas contendo cana-deaçúcar tratada com óxido de cálcio. Revista Brasileira de Zootecnia, Viçosa, MG, v. 39, n. 10, p. 2253-2261, 2010.

GERON, L. J. V.; COSTA, F. G.; SANTOS, R. H. E.; GARCIA， J.; TRAUTMANN-MACHADO， R. J.; SILVA, M. I. L.; ZEOULA, L. M.; SILVA, A. V. Balanço de nitrogênio em cordeiros alimentados com rações contendo diferentes teores de concentrado. Semina: Ciências agrárias, Londrina, v. 36, n. 3, p. 1609-1622, 2015a.

GERON, L. J. V.; GARCIA, J.; COELHO, K. S. M.; AGUIAR, S. C.; ZANINE, A. M.; SOUZA, A. L.; CARVALHO, J. T. H.; ROBERTO, L. S.; SOUSA NETO, E. L.; FERREIRA, D. J. In vitro digestibility and nutritional characterization of distillers dried grains with solubles according to the Cornell Net Carbohydrate and Protein System. Semina: Ciências Agrárias, Londrina, v. 38, n. 3, p. 2029-2040, 2017.

GERON, L. J. V.; GARCIA, J.; COSTA, F. G.; AGUIAR, S. C.; OLIVEIRA, E. B.; SILVA, M. I. L.; CABRAL, L. S.; PIERANGELI, M. A. P.; ZEOULA, L. M.; MEXIA, A. A. Ruminal parameters and nitrogen balance in sheep fed diets containing residue from the extraction of tamarind pulp. Semina: Ciências Agrárias, Londrina, v. 36, n. 5, p. 3411-3420, 2015 b.

GERON. L. J. V.; COSTA, F. G.; GARCIA, J.; ZANINE, A. M.; OLIVIERA, E. B.; CABRAL, L. S.; PEIRANGELI, M. A. P.; AGUIAR, S. C. Nutrients intake and digestibility in sheep fed with residue from the extraction of tamarind pulp. Semina: Ciências Agrárias, Londrina, v. 36, n. 6, p. 4401-4412, 2015c. Suplement 2.

KIM, S.; DALE, B. E. Environmental aspects of ethanol derived from no-tilled corn grain: nonrenewable energy consumption and greenhouse gas emissions. Biomass and Bioenergy, Melia Sitges, v. 28, n. 2, p. 475-489, 2005.

KOZLOSKE, G. V. Bioquímica dos ruminantes. Santa Maria: Universidade Federal de Santa Maria, UFSM, 2002. $140 \mathrm{p}$.

MORENO, G. M. B.; SILVA SOBRINHO, A. G.; LEÃO, A. G.; LOUREIRO, C. M. B.; PEREZ, H. L.; ROSSI, R. C. Desempenho, digestibilidade e balanço de nitrogênio em cordeiros alimentados com silagem de milho ou canade-açúcar e dois níveis de concentrado. Revista Brasileira de Zootecnia, Viçosa, MG, v. 39, n. 4, p. 853-860, 2010.

NATIONAL RESEARCH COUNCIL - NRC. Nutrient requirements of small ruminants: sheep, goats, cervids, and New World camelids. Washington: National Academy Press, 2007. 384 p.

NUEZ-ORTÍN, W. G.; YU, P. Nutrient variation and availability of wheat DDGS, corn DDGS and blend DDGS from bioethanol plants. Journal of the Science of Food and Agriculture, London, v. 89, n. 4, p. 1754-1761, 2009.

RAUSCH, K. D.; BELYEA, R. L. Coproducts from bioprocessing of corn. In: ASAE ANNUAL INTERNATIONAL MEETING, 2005, Tampa. Proceedings... Tampa: FL, United States, 2005. p. 17-20.

SALIM, H. M.; KRUK, Z. A.; LEE, B. D. Nutritive value of corn distillers dried grains with solubles as na ingredient of poultry diets: a review. World's Poultry Science Journal, Cambridge, v. 66, n. 8, p. 411-432, 2010. 
SCHONE, R. A. Resíduo seco de destilaria com solúveis (DDGS) na alimentação de frangos de corte. 2015. Dissertação (Mestrado em Nutrição e Produção Animal) - Programa de Pós-Graduação em Zootecnia - Universidade Estadual do Oeste do Paraná, Marechal Candido Rondon.

SILVA, D. J.; QUEIROZ. A. C. Análise de alimentos: métodos químicos e biológicos. 2. ed. Viçosa, MG: UFV, 2002. 178 p.
UNIVERSIDADE FEDERAL DE VIÇOSA - UFV. Sistemas de análises estatísticas e genéticas - SAEG. Versão 9.1. Manual do usuário. Viçosa, MG: Imprensa Universitária, 2007. 150 p.

VAN SOEST, P. J.; ROBERTSON, J. B.; LEWIS, B. A. Methods for dietary fiber, neutral detergent fiber, and nonstarch polysaccharides in relation to animal nutrition. Journal of Dairy Science, Champaign, v. 74, n. 12, p. 3583-3597, 1991. 
